\title{
STUDY OF THE EFFECTS OF CARBON AND GLASS FIBRE REINFORCEMENT AND OTHER FILLERS ON ELEVATED TEMPERATURE RESISTANT PROPERTIES OF ER MATRIX COMPOSITES
}

\author{
Md Nadeem M ${ }^{1}$, K Chandrashekara ${ }^{2}$, Yathisha $\mathrm{N}^{3}$, Rudramurthy ${ }^{4}$ \\ ${ }^{I}$ Department of Mechanical Engineering, ATME College of Engineering, Mysore, Karnataka, India \\ ${ }^{2}$ Department of Mechanical Engineering, SJCE, Mysore Karnataka, India \\ ${ }^{3}$ Department of Mechanical Engineering, ATME College of Engineering, Mysore, Karnataka, India \\ ${ }^{4}$ Department of Mechanical Engineering, SJCE, Mysore Karnataka, India
}

\begin{abstract}
In the present study, composite materials required for elevated temperature applications were fabricated using vacuum bagging technique. Epoxy Resin (ER-VP401) was used as the matrix and Glass fibre was used as reinforcement. $\mathrm{SiC}, \mathrm{Al}_{2} \mathrm{O}_{3}$ and others were used as fillers to bring in elevated temperature resistance. These composites were subjected to mechanical tests like Tensile, Hardness and Impact test. Tribological tests like two body abrasion and Pin on disc (POD) were carried out. Tensile strength, hardness and impact energy were improved with increase in fillers content. Wear resistance also improved with increase in percentage of fillers substantially. SEM micrographs are used to explain the mechanism of the material strengthening at elevated temperatures.
\end{abstract}

Keywords: Epoxy resin, Glass Fiber $(\mathrm{GF}), \mathrm{Al}_{2} \mathrm{O}_{3}, \mathrm{SiC}$, Elevated Temperature Resistance.

\section{INTRODUCTION}

The materials used to manufacture various products are supposed to fulfill several criteria before being approved. Some of the criteria are the results of regulation and legislation with the environmental and safety concerns and some are the requirements of the customers. Composite material is a combination of two or more materials to form a new material system with enhanced material properties. After being solely used for their electromagnetic properties (insulators and radar-domes), using composites to improve the structural performance of spacecraft and military aircraft became popular in the last two decades. Nowadays, cost reduction during manufacturing and operation are the main technology drivers. Fibers or particles embedded in matrix of another material are the best example of modern-day composite materials.

For most structural applications in the current aircraft designs, polymer composites has been adequately used and implemented for a wide range of applications in areas where high temperatures are encountered. The usage of such composites, even for primary loadbearing structures in military fighters, transport aircraft, satellites and space vehicles has been beneficially realized. Attention is now focused on expanding the usage of such composites to other areas where temperatures could be higher in the range of 200- $400^{\circ} \mathrm{C} \quad[1]$ Multi-Walled Carbon Nanotubes functionalized with amino groups (MWCNT-NH2) via chemical modification of the carboxyl groups introduced on the surface of MWCNT. The thermal diffusivity and conductivity of all of the composites continuously improved with increasing content of fillers [2]. The behavior of Glass Fiber-Reinforced Polymer (GFRP) bars subjected to extreme temperatures is very critical for industrial applications. They evaluated the variation of mechanical properties of sand-coated GFRP reinforcing bars subjected to low temperatures (ranging from 0 to $-100^{\circ} \mathrm{C}$ ) and elevated temperatures (ranging from 23 to $315^{\circ} \mathrm{C}$ ). Tensile, shear and flexural properties improved as the glass fiber content increased [3]. The effect of addition of Silicon Carbide (SiC) filler in different weight percentages on physical properties, mechanical properties, and thermal properties of chopped glass fiber-reinforced epoxy composites has been investigated. The result showed that the physical and mechanical properties of SiC-filled glass fiberreinforced epoxy composites were better than unfilled glass fiber-reinforced epoxy composites [4]. [5] Presented results of an experimental and analytical study about the mechanical behavior at elevated temperatures of Glass Fiber Reinforced Polymer (GFRP) pultruded profiles made of polyester resin and E-glass fibers. [6] observed the mechanical properties of Vapor Grown Carbon Nano fiber (VGCNF)polymer composites. They studied the structural and intrinsic mechanical properties of VGCNFs. Then the major factors (filler dispersion and distribution, filler aspect ratio, adhesion and interface between filler and polymer matrix) affecting the mechanical properties of VGCNF/polymer composites were presented. The effect of fiber content and fiber orientation on the strength of composites was studied to estimate the tensile strength out of fibre orientation and fibre content [7]. 
The F584/PW Pre-Impregnated materials (prepregs) presented the highest values of tensile strength while the highest modulus results were obtained for the 8HS composite laminates [8]. [9] Conducted a research on epoxy resin polymers reinforced with natural fibers like Sisal, Banana and Roselle and three hybrid combinations of any two fibers. Less elongation and fiber pull out and brittle nature of fracture were observed in fiber based composites while more elongation, fiber pull out and partial brittle nature of fracture were observed in hybrid composites. It was seen from the results that well dispersed Nano particles of $\mathrm{CaCO}_{3}$ up to the weight percentage of 15 increases the impact strength of the composite [10]. [11] Conducted impact tests on aluminum filled milled (carbon and glass) fiber reinforced epoxy based polymer composites. The milled fiber addition slightly increased the impact resistance of the composites. [12] Studied the impact resistance of epoxy based composites reinforced with fiber and hybrid of sisal, banana and Roselle fibers. The results showed that the hybrid composites absorbed more impact energy before fracture. The greater level of fiber pull out observed in specimens fabricated using hybrid reinforcement, leads to superior impact strength. The effect of the reinforcement of thermosetting polyester with short glass fibers on mechanical properties and tribological behavior was studied. The friction and wear-behavior as a function of sliding speed and fiber-glass proportion (0 to 50\%). Wear resistance behavior increased with increase in glass fiber and filler content [13]. [14] Investigated that the tribological behavior was found to depend on the filler materials in the tested composites and better results were obtained for the composite containing solid lubricants (Polytetrafluoroethylene (PTFE) and graphite). [15] Observed that the wear loss increases with increase in normal load. The optimum wear reduction was obtained with $40 \%$ fiber content.

The objective of the present study is to investigate the effect of filler materials on the mechanical properties of the selected polymer matrix composite at elevated temperature. The composition of the specimens is given in table- 1 .

\section{MATERIALS AND METHODS}

Table-1: composition of the specimens

\begin{tabular}{|l|l|l|l|l|l|}
\hline Components' percentage & \multicolumn{5}{l}{ Specimen No } \\
\cline { 2 - 7 } by weight & $\mathbf{1}$ & $\mathbf{2}$ & $\mathbf{3}$ & $\mathbf{4}$ & $\mathbf{5}$ \\
\hline Epoxy Resin & 50 & 50 & 50 & 50 & 50 \\
\hline Activated Carbon Powder & 10 & 10 & 10 & 10 & 10 \\
\hline Chopped E - Glass fiber & 10 & 10 & 10 & 10 & 10 \\
\hline Sodium Sulphide $\left(\mathrm{Na}_{2} \mathrm{~S}\right)$ & 5 & 5 & 5 & 5 & 5 \\
\hline Sintered Clay & 5 & 5 & 5 & 5 & 5 \\
\hline Silicon Carbide $(\mathrm{SiC})$ & 20 & 15 & 10 & 5 & 0 \\
\hline Aluminium Oxide $\left(\mathrm{Al}_{2} \mathrm{O}_{3}\right)$ & 0 & 5 & 10 & 15 & 20 \\
\hline
\end{tabular}

\subsection{Specimen Preparation and Experimental Set Up}

Table I gives the materials used in the present study. Epoxy resin is kept constant at $50 \mathrm{Wt} \%$. Activated carbon powder and chopped $\mathrm{E}$ glass fibre were kept at $10 \mathrm{Wt} \%$ respectively, sodium sulphide and sintered clay were used as fillers to

bring in elevated temperature resistance properties and they were kept at $5 \mathrm{Wt} \%$ each. Silicon carbide $(\mathrm{SiC})$ and Aluminum oxide $\left(\mathrm{Al}_{2} \mathrm{O}_{3}\right)$ were varied from $0-20 \mathrm{Wt} \%$ each.

First the materials are weighed as required, and then they are put together and mixed well. The mixture is then poured into a prepared mould of the required thickness. It should be noted that the epoxy resin and hardener start to set i.e. start solidifying after 30 minutes of mixing and hence, the mixture should be poured into the mould before the setting time. The mixture is poured in excess and suitable weights are applied on it. Similarly, five different compositions are poured in separate moulds by varying the $\mathrm{SiC}$ and $\mathrm{Al}_{2} \mathrm{O}_{3}$ content while keeping all the other weight percentages constant. The content of $\mathrm{SiC}$ and $\mathrm{Al}_{2} \mathrm{O}_{3}$ are varied in steps of five percent in such a way that in any composition, the sum of $\mathrm{SiC}$ and $\mathrm{Al}_{2} \mathrm{O}_{3}$ is 20 percent of the total weight. The moulds are then left for 24 hours to solidify and cure at room temperature. After solidification, the specimens are removed from the mould and post cured at $100^{\circ} \mathrm{C}$ for 2 hours in a hot air oven. The specimens are then taken out and labeled. The specimens are then marked as per the test standards. Specimens were prepared for tensile, impact strength and wear tests. Figure-1 shows the specimen preparation pictures.

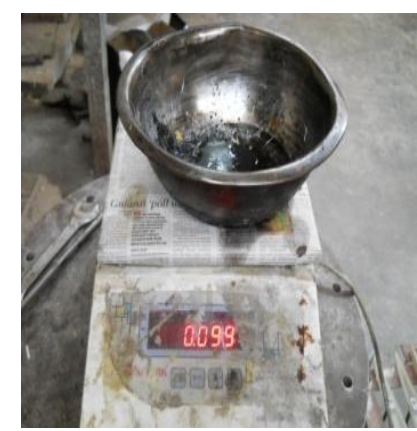

(a) Weighing the constituents in right Proportion

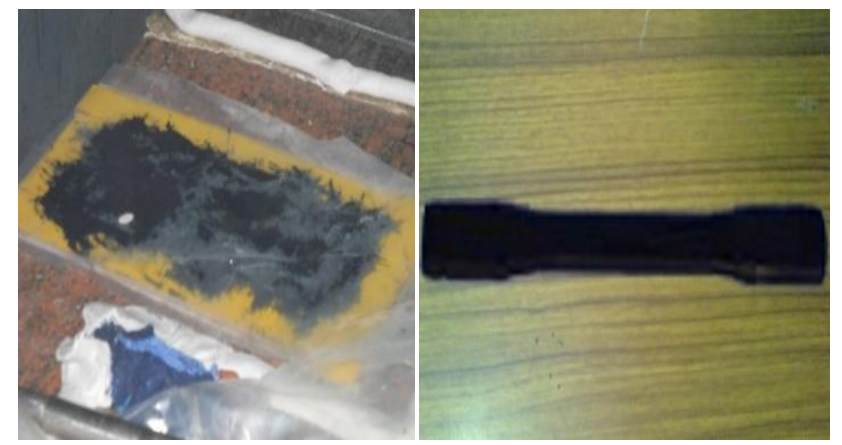

(c) Pouring the mixture into the

(d) Specimens Moulds Fig-1- Preparation of Specimens

To determine the mechanical properties of the material the following tests were conducted.

A. Tensile test- Tensile tests were conducted according to the ASTM D-638. Computerized Universal Testing Machine (UTM) used for this purpose and the loading arrangement is shown in Figure. 2(a). Specifications are also mentioned. The dimension of the tensile 
specimen was $165 \mathrm{~mm} \times 19 \mathrm{~mm} \times 3.2 \mathrm{~mm}$. Gauge length was $50 \mathrm{~mm}$. Results were used to calculate the tensile strength of composite samples.

B. Impact test - Izod impact tests were conducted on Vnotched composite specimen according to ASTM D256. A Pendulum impact tester, shown in Figure 2(b) was used for this purpose. Dimension of the specimen were $64 \mathrm{~mm} \times 12.5 \mathrm{~mm} \times 3.2 \mathrm{~mm}$. The pendulum impact testing machine ascertains the impact strength of the material by shattering the specimen with a pendulum hammer, measuring the spent energy and relating it to the cross section of the specimen. The respective values of impact energy of different specimen are recorded directly from the digital indicator and reported.

C. Hardness test - Shore-D hardness tests were conducted on specimen according to ASTM D2240 using Durometer shown in Figure 2(c). The hardness tester is placed on the specimen and pressure is applied so that the flats underneath the tester touch the surface of the specimen. The readings are taken directly from the dial. The specimens are then heated to different temperatures and the readings are taken to determine the variation in the hardness of the specimen with respect to temperature.

D. Wear test - Wear tests were conducted according to the ASTM using Pin on Disc Machine (POD).The machine and its specifications are given in Figure 2(d). Dry sliding tests were conducted at ambient conditions with the loads of $4 \mathrm{Kg}, 8 \mathrm{Kg}, 12 \mathrm{Kg}$ and $16 \mathrm{Kg}$. Disc speed was kept at 1000rpm with track diameter of $40 \mathrm{~mm}$, resulting in a sliding velocity of $3.92 \mathrm{~m} / \mathrm{s}$. The tests were conducted for two minutes or the length of time until the specimen withstands the maximum load and failed whichever being the earliest. The temperature of the tip of the specimen was registered using the optical pyrometer. Wear of the materials considered was measured by loss in length which is then converted into wear volume using the measured cross-sectional area data. The specific Wear rate $\left(\mathrm{K}_{\mathrm{s}}\right)$ was calculated from the below equation (1).

$$
K_{s}=\frac{\Delta V}{P \times D} \text { in } \frac{m^{3}}{N-m}
$$

Where, $\Delta \mathrm{V}$ is the volume loss in $\mathrm{m}^{3}, \mathrm{P}$ is the load in Newton; $\mathrm{D}$ is the sliding distance in meters.

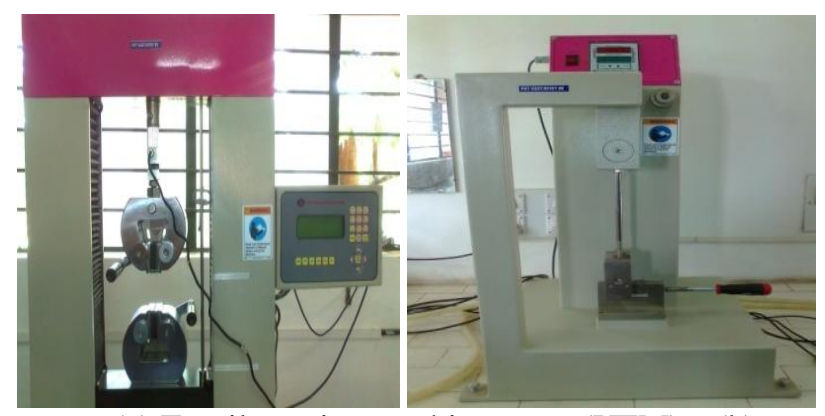

(a) Tensile testing machine setup (UTM) (b)

Computerized impact testing machine

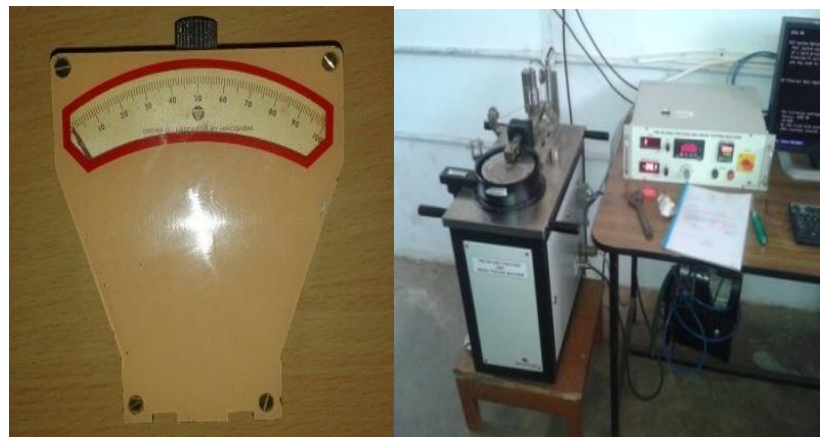

(c) Shore-D hardness testing machine (d) Pin on disc machine

Fig-2- Testing machines

\section{RESULTS AND DISCUSSIONS}

Physical and mechanical properties describe the behavior of materials when they are used in practical applications. The properties such as hardness describe the physical state of the system. The mechanical property of the material is a measure of the behavior of the material under different loading conditions. Tests were done to notice the effect of variation of filler content on the physical and mechanical properties and the optimum filler loading of carbon-glass reinforced polymer composites at which specific Specific Wear rate is least.

\subsection{Effect of $\mathrm{SiC}$ and $\mathrm{Al}_{2} \mathrm{O}_{3}$ on Tensile Strength of}

\section{Carbon-Glass Reinforced Polymer Composites}

The tensile strength is an engineering value that is calculated by dividing the maximum load on the material by the initial cross sectional area of the test specimen. The Table II shows the results obtained during the tensile test conducted on all the five specimens.

Table-:2 tensile strength of cgrp composites

\begin{tabular}{|l|l|l|}
\hline $\begin{array}{l}\text { Specimen } \\
\text { No. }\end{array}$ & Filler Content & $\begin{array}{l}\text { Ultimate Tensile } \\
\text { Strength (MPa })\end{array}$ \\
\hline 1 & $\begin{array}{l}20 \% \quad \mathrm{SiC}, \quad 0 \% \\
\mathrm{Al}_{2} \mathrm{O}_{3}\end{array}$ & 15.38 \\
\hline 2 & $\begin{array}{l}15 \% \quad \mathrm{SiC}, 05 \% \\
\mathrm{Al}_{2} \mathrm{O}_{3}\end{array}$ & 17.31 \\
\hline 3 & $\begin{array}{l}10 \% \quad \mathrm{SiC}, \quad 10 \% \\
\mathrm{Al}_{2} \mathrm{O}_{3}\end{array}$ & 19.35 \\
\hline 4 & $\begin{array}{l}05 \% \quad \mathrm{SiC}, \quad 15 \% \\
\mathrm{Al}_{2} \mathrm{O}_{3}\end{array}$ & 20.98 \\
\hline 5 & $\begin{array}{l}0 \% \mathrm{SiC}, \quad 20 \% \\
\mathrm{Al}_{2} \mathrm{O}_{3}\end{array}$ & 25.28 \\
\hline
\end{tabular}

The graph for the tensile strength is shown in Figure 3.1 


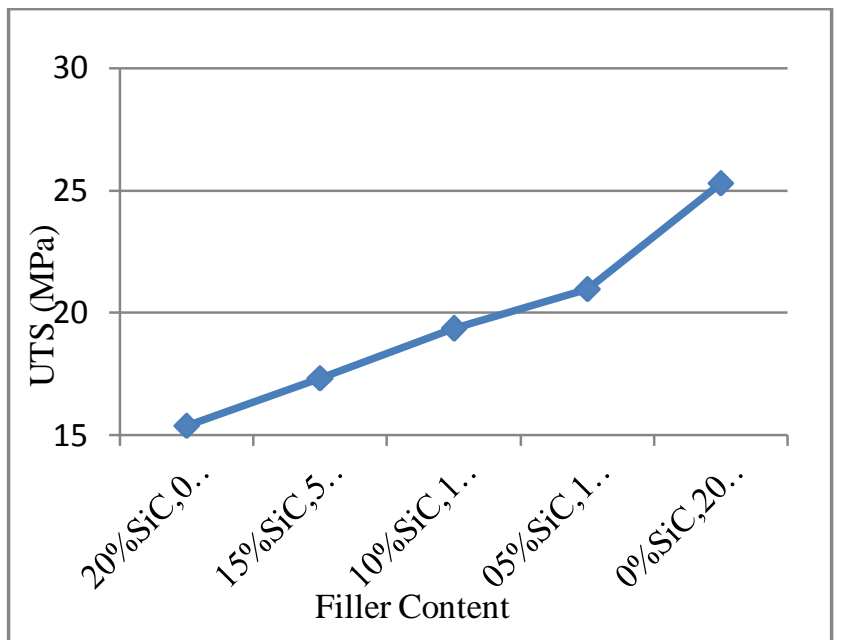

Fig 3.1 - Effect of $\mathrm{SiC}$ and $\mathrm{Al}_{2} \mathrm{O}_{3}$ on Ultimate Tensile Strength (UTS) on CGRP Composites

From the graph 3.1 , it can be seen that the tensile strength is highest in the composite with $20 \% \quad \mathrm{Al}_{2} \mathrm{O}_{3}$ and no $\mathrm{SiC}$, and lowest in that with $20 \% \mathrm{SiC}$ and no $\mathrm{Al}_{2} \mathrm{O}_{3}$. The tensile strength increases proportionally with the increase in $\mathrm{Al}_{2} \mathrm{O}_{3}$ content and decrease in $\mathrm{SiC}$ content since the tensile strength of $\mathrm{Al}_{2} \mathrm{O}_{3}$ is higher than that of $\mathrm{SiC}$. But complete absence of $\mathrm{SiC}$ in the fifth composite specimen results in a higher tensile strength which is not in proportion with the tensile strengths of other specimens. This is due to the presence of higher percentage of $\mathrm{Al}_{2} \mathrm{O}_{3}$ alone and no $\mathrm{SiC}$. The $\mathrm{Al}_{2} \mathrm{O}_{3}$ particles which fill the composite, due to their higher tensile strength can withstand more loads and transfer it to the adjacent particle at the same time, thus reducing the load concentration at a single point which in turn reduces the stress concentration thereby increasing the ultimate tensile strength of the specimen. Also, the $\mathrm{Al}_{2} \mathrm{O}_{3}$ particles which are smaller than the $\mathrm{SiC}$ particles have a higher density compared to the $\mathrm{SiC}$ density. The higher density results in a uniform and continuous distribution of the filler and lower bonding surface resulting in increase in bonding strength which also results in increase in the tensile strength of the specimen.

The specimen with $20 \% \mathrm{SiC}$ and $0 \% \mathrm{Al}_{2} \mathrm{O}_{3}$ has the least tensile strength of the five compositions. This is due to the low tensile strength of SiC and its larger particle size. While the low tensile strength of SiC hampers the tensile strength of the specimen directly by failing at lower loads, the larger particle size of $\mathrm{SiC}$ results in a discrete distribution of filler along with an increase in bonding surface area which decreases the binding strength, thereby decreases the tensile strength of the specimen.

\subsection{Effect of $\mathrm{SiC}$ and $\mathrm{Al}_{2} \mathrm{O}_{3}$ on Impact Strength of}

\section{Carbon-Glass Reinforced Polymer Composites}

The material's resistance to fracture is known as toughness. It is the energy absorbed by the material before fracture and is expressed in terms of the same. A ductile material can absorb considerable amount of energy before fracture while a brittle material absorbs very little energy before fracture.
Table IIIshows the results obtained during the impact test conducted on all the five specimens.

Table-3: Impact Strength Of Cgrp Composites

\begin{tabular}{|c|c|c|}
\hline $\begin{array}{l}\text { Specimen } \\
\text { No. }\end{array}$ & Filler Content & $\begin{array}{l}\text { Impact } \\
\text { Energy ( J ) }\end{array}$ \\
\hline 1 & $20 \% \mathrm{SiC}, 0 \% \mathrm{Al}_{2} \mathrm{O}_{3}$ & 1 \\
\hline 2 & $\begin{array}{lll}15 \% & \mathrm{SiC}, & 05 \% \\
\mathrm{Al}_{2} \mathrm{O}_{3} & & \\
\end{array}$ & 0.45 \\
\hline 3 & $\begin{array}{lll}10 \% & \mathrm{SiC}, & 10 \% \\
\mathrm{Al}_{2} \mathrm{O}_{3} & & \\
\end{array}$ & 0.45 \\
\hline 4 & $\begin{array}{lll}05 \% & \mathrm{SiC}, & 15 \% \\
\mathrm{Al}_{2} \mathrm{O}_{3} & & \\
\end{array}$ & 1.3 \\
\hline 5 & $0 \% \mathrm{SiC}, 20 \% \mathrm{Al}_{2} \mathrm{O}_{3}$ & 0.6 \\
\hline
\end{tabular}

The graph for the impact strength is shown in Figure 3.2

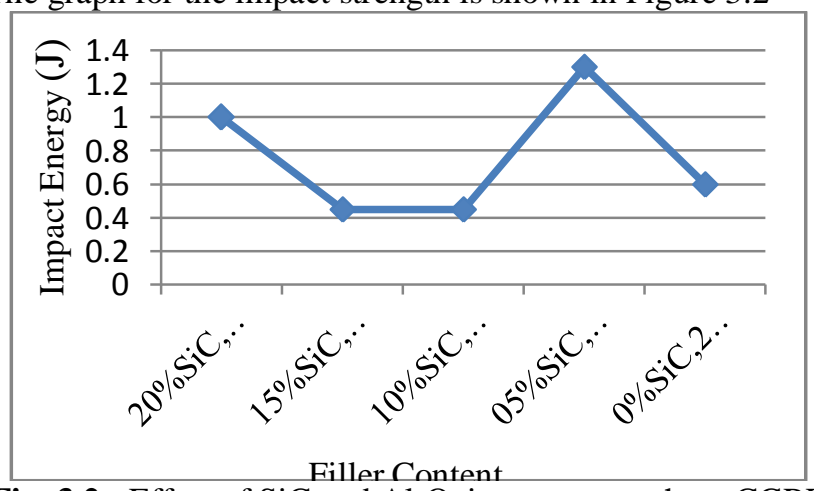

Fig. 3.2 - Effect of $\mathrm{SiC}$ and $\mathrm{Al}_{2} \mathrm{O}_{3}$ impact strength on CGRP Composites

From table III, it is observed that the impact energy is the highest for the composite having $05 \% \mathrm{SiC}$ and $15 \% \mathrm{Al}_{2} \mathrm{O}_{3}$. The fracture toughness for $\mathrm{SiC}$ is 1.5 times greater than that of $\mathrm{Al}_{2} \mathrm{O}_{3}$. Glass fiber has least fracture toughness, at the highest percentage of silicon impact strength is $1 \mathrm{~J}$, but it has decreased to $0.45 \mathrm{~J}$.It has remained the same for the further decrease in $\mathrm{SiC}$, indicating the fracture toughness of both $\mathrm{SiC}$ and $\mathrm{Al}_{2} \mathrm{O}_{3}$ are contributing to the increase in impact strength, contribution from $\mathrm{Al}_{2} \mathrm{O}_{3}$ being higher. This emphasizes the further increase in $\mathrm{Al}_{2} \mathrm{O}_{3}$ percentage has increased the impact strength significantly (up to $15 \%$ of $\mathrm{Al}_{2} \mathrm{O}_{3}$ ).

The conclusion is that relatively lesser percentage of $\mathrm{SiC}$ is a must for increase in impact strength irrespective of increase in $\mathrm{Al}_{2} \mathrm{O}_{3}$. This observation is evident as the impact strength has decreased drastically for $0 \%$ of $\mathrm{SiC}$.

\subsection{Effect of $\mathrm{SiC}$ and $\mathrm{Al}_{2} \mathrm{O}_{3}$ on Wear Resistance of}

\section{Carbon-Glass Reinforced Polymer Composites}

Wear is the sideways erosion of material on a solid surface due to the action of another surface. A material is said to possess good wear properties when less amount of material gets eroded due to the friction. Table 3.3 shows the results obtained during the wear test conducted on all the specimens. 
Speed of the disc $=1000 \mathrm{rpm}=4.18 \mathrm{~m} / \mathrm{s}$

Radius of the disc $=40 \mathrm{~mm}$

Diameter of each specimen $=6 \mathrm{~mm}$

Length of each specimen $=30 \mathrm{~mm}$

Table 4: wear properties of cgrp composites

\begin{tabular}{|c|c|c|c|c|c|c|}
\hline \multirow{2}{*}{$\begin{array}{l}\text { Speci } \\
\text { men } \\
\text { No. }\end{array}$} & & \multicolumn{5}{|l|}{$\operatorname{Load}(\mathrm{N})$} \\
\hline & & 39.24 & 78.48 & & 117.72 & \\
\hline 1 & $\begin{array}{l}\text { Specific } \\
\text { Wear rate } \\
\left(\mathrm{mm}^{3} / \mathrm{Nm}\right)\end{array}$ & $\begin{array}{l}2.722 \\
10^{-5}\end{array}$ & $\begin{array}{l}7.23 \\
10^{-5}\end{array}$ & & $\begin{array}{l}13.19 \\
10^{-5}\end{array}$ & \\
\hline 2 & $\begin{array}{l}\text { Specific } \\
\text { Wear rate } \\
\left(\mathrm{mm}^{3} / \mathrm{Nm}\right)\end{array}$ & $\begin{array}{l}9.88 \\
10^{-5}\end{array}$ & $\begin{array}{l}8.814 \\
10^{-5}\end{array}$ & $X$ & $\begin{array}{l}8.743 \\
10^{-5}\end{array}$ & $\mathrm{x}$ \\
\hline 3 & $\begin{array}{l}\text { Specific } \\
\text { Wear rate } \\
\left(\mathrm{mm}^{3} / \mathrm{Nm}\right)\end{array}$ & $\begin{array}{l}3.14 \\
10^{-5}\end{array}$ & $\begin{array}{l}6.28 \\
10^{-5}\end{array}$ & & $\begin{array}{l}8.743 \\
10^{-5}\end{array}$ & $\mathrm{x}$ \\
\hline 4 & $\begin{array}{l}\text { Specific } \\
\text { Wear rate } \\
\left(\mathrm{mm}^{3} / \mathrm{Nm}\right)\end{array}$ & $\begin{array}{l}2.28 \\
10^{-5}\end{array}$ & $\begin{array}{l}7.57 \\
10^{-5}\end{array}$ & & $\begin{array}{l}5.712 \\
10^{-5}\end{array}$ & $\mathrm{x}$ \\
\hline 5 & $\begin{array}{l}\text { Specific } \\
\text { Wear rate } \\
\left(\mathrm{mm}^{3} / \mathrm{Nm}\right)\end{array}$ & $\begin{array}{l}2.86 \\
10^{-5}\end{array}$ & $\begin{array}{l}5.589 \\
10^{-5}\end{array}$ & & $\begin{array}{l}4.52 \\
10^{-5}\end{array}$ & $\mathrm{x}$ \\
\hline
\end{tabular}

Figure 3.3 shows the variation of Specific Wear rate with respect to weight graphically

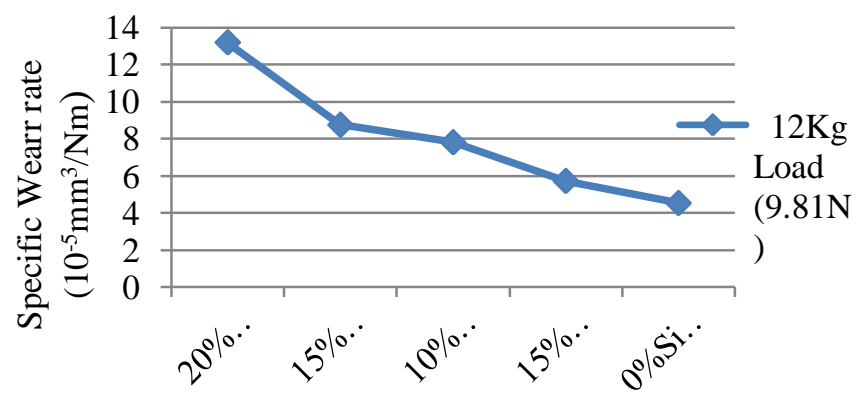

Filler Content

Fig. 3.3 - Effect of $\mathrm{SiC}$ and $\mathrm{Al}_{2} \mathrm{O}_{3}$ on Wear resistance of CGRP Composite at maximum load

\subsection{Effect of Temperature on Hardness of Carbon-}

\section{Glass Reinforced Polymer Composites}

Hardness is a measure of how resistant a solid matter is to various kinds of permanent shape change when a force is applied. The hardness readings of the specimens were obtained directly from the Shore-D hardness tester. The specimens were heated to six different temperatures by a hot air oven and the readings were taken. Table $\mathrm{V}$ shows the readings thus obtained.
Table 5: Effect Of Temperature On Hardness Of Cgrp Composites

\begin{tabular}{|c|c|c|c|c|c|c|c|}
\hline \multirow{4}{*}{ Specimen No. } & \multicolumn{7}{|c|}{ Temperature $\left({ }^{\circ} \mathrm{C}\right)$} \\
\hline & 2 & 5 & 8 & 11 & 14 & 17 & 20 \\
\hline & 7 & 7 & 7 & 7 & 7 & 7 & 7 \\
\hline & \multicolumn{7}{|c|}{ Shore-D Hardness no. } \\
\hline \multirow{2}{*}{$\begin{array}{l}1-20 \% \quad \mathrm{SiC}, \quad 0 \% \\
\mathrm{Al}_{2} \mathrm{O}_{3}\end{array}$} & 9 & 8 & 8 & \multirow{2}{*}{80} & \multirow{2}{*}{71} & \multirow{2}{*}{71} & \multirow{2}{*}{58} \\
\hline & 0 & 8 & 5 & & & & \\
\hline \multirow{2}{*}{$\begin{array}{l}2-15 \% \mathrm{SiC}, 05 \% \\
\mathrm{Al}_{2} \mathrm{O}_{3}\end{array}$} & 8 & 8 & 8 & \multirow{2}{*}{86} & \multirow{2}{*}{86} & \multirow{2}{*}{80} & \multirow{2}{*}{70} \\
\hline & 9 & 8 & 7 & & & & \\
\hline \multirow{2}{*}{$\begin{array}{l}3-10 \% \mathrm{SiC}, 10 \% \\
\mathrm{Al}_{2} \mathrm{O}_{3}\end{array}$} & 8 & 8 & 8 & \multirow{2}{*}{82} & \multirow{2}{*}{78} & \multirow{2}{*}{73} & \multirow{2}{*}{58} \\
\hline & 5 & 4 & 4 & & & & \\
\hline \multirow{2}{*}{$\begin{array}{l}4-05 \% \mathrm{SiC}, 15 \% \\
\mathrm{Al}_{2} \mathrm{O}_{3}\end{array}$} & 8 & 8 & 8 & \multirow{2}{*}{86} & \multirow{2}{*}{72} & \multirow{2}{*}{65} & \multirow{2}{*}{63} \\
\hline & 9 & 8 & 8 & & & & \\
\hline \multirow{2}{*}{$\begin{array}{l}5-0 \% \quad \mathrm{SiC}, \quad 20 \% \\
\mathrm{Al}_{2} \mathrm{O}_{3}\end{array}$} & 8 & 8 & 8 & \multirow{2}{*}{80} & \multirow{2}{*}{78} & \multirow{2}{*}{65} & \multirow{2}{*}{64} \\
\hline & 9 & 7 & 4 & & & & \\
\hline \multirow{2}{*}{$\begin{array}{l}\text { Average Shore-D } \\
\text { Hardness no }\end{array}$} & 8 & 8 & 8 & \multirow{2}{*}{83} & \multirow{2}{*}{77} & \multirow{2}{*}{71} & \multirow{2}{*}{63} \\
\hline & 9 & 7 & 6 & & & & \\
\hline
\end{tabular}

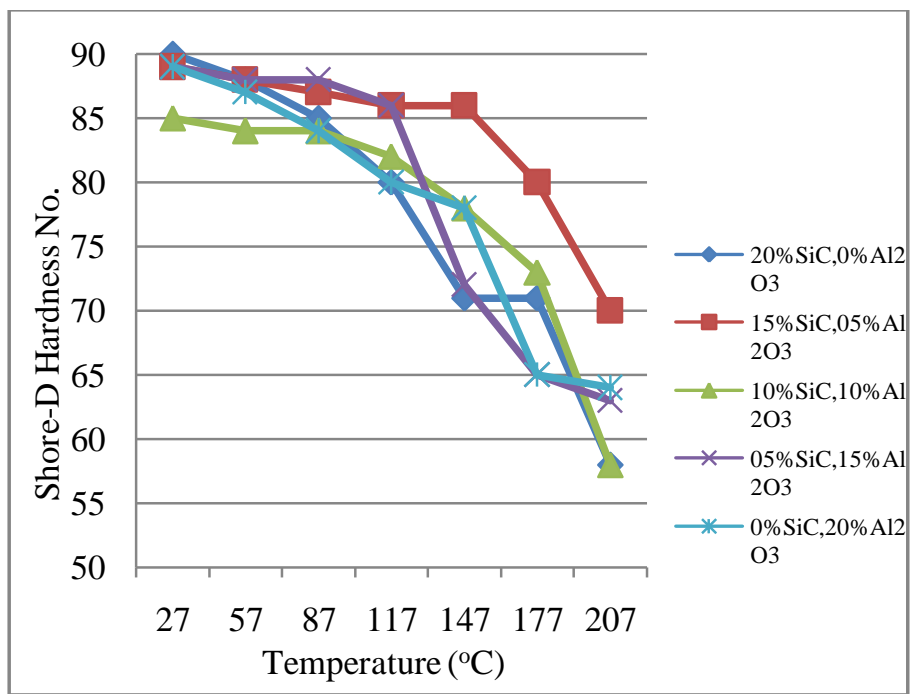

Fig. 3.4 - Variation of Shore-D hardness of CGRP Composites with temperature

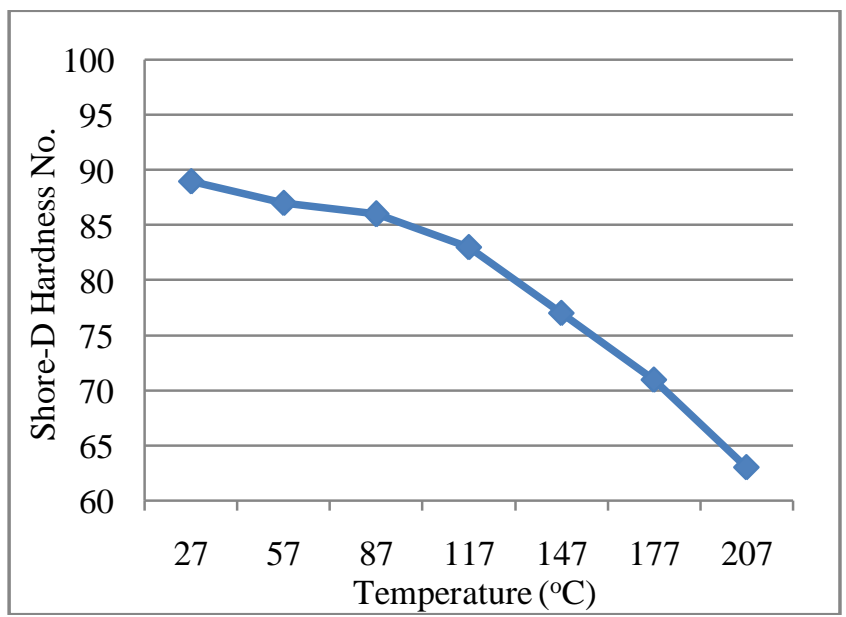

Fig. 3.5 - Variation of average hardness of CGRP Composites with temperature 
It could be seen from the Table $\mathrm{V}$ and Fig 3.5 the average Shore-D hardness value obtained at room temperature for the entire specimen considered irrespective of the percentage by weight of $\mathrm{SiC}$ and $\mathrm{Al}_{2} \mathrm{O}_{3}$ is 89 . Similarly, the average values of hardness for considered specimen at temperatures greater than the room temperature is steps of $30^{\circ} \mathrm{C}$ upto $207^{\circ} \mathrm{C}$ are $87,86,83,77,71,63$.

From $27^{\circ} \mathrm{C}$ (room temperature) to $117^{\circ} \mathrm{C}$, the hardness value has decreased by $6.7 \%$, which is not very significant. From $147^{\circ} \mathrm{C}$ to $207^{\circ} \mathrm{C}$, the percentage decreased in Shore-D hardness is $18.2 \%$, which is significant. This means that the considered specimen can retain their hardness up to $120^{\circ} \mathrm{C}$. Hardness of the $\mathrm{SiC}$ is 2.3 times greater than that of $\mathrm{Al}_{2} \mathrm{O}_{3}$, the thermal conductivity of $\mathrm{SiC}$ is 6.6 times greater than that of $\mathrm{Al}_{2} \mathrm{O}_{3}$. Whereas, the coefficient of thermal expansion of $\mathrm{Al}_{2} \mathrm{O}_{3}$ is 2 times greater than that of $\mathrm{SiC}$.

At room temperature, the average value of Shore-D hardness is about 89 . This value has decreased slightly up to $87^{\circ} \mathrm{C}$,from $87^{\circ} \mathrm{C}$ up to $117^{\circ} \mathrm{C}$ the decrease in value is about $3.48 \%$. Further increase in temperature in steps of $30^{\circ} \mathrm{C}$ up to $207^{\circ} \mathrm{C}$, the percentage decrease is $6.89 \%$.

The reason is that higher percentage of $\mathrm{SiC}$ has contributed to the average hardness of all the specimens considered up till $117^{\circ} \mathrm{C}$.Slight Decrease in hardness in this temperature range is attributed to increase in percentage of $\mathrm{Al}_{2} \mathrm{O}_{3}$, which has got comparatively higher hardness, beyond $117^{\circ} \mathrm{C}$ one must note that $\mathrm{SiC}$ percentage has decreased and $\mathrm{Al}_{2} \mathrm{O}_{3}$ percentage has increased.

By the order of magnitude of hardness of $\mathrm{SiC}$ and $\mathrm{Al}_{2} \mathrm{O}_{3}$ it is evident that the hardness has decreased quite drastically up to $207^{\circ} \mathrm{C}$. The synergy of these fillers has come to play up to $117^{\circ} \mathrm{C}$ and it has seized to exist from $117^{\circ} \mathrm{C}$ to $207^{\circ} \mathrm{C}$.

\section{SEM MORPHOLOGY}

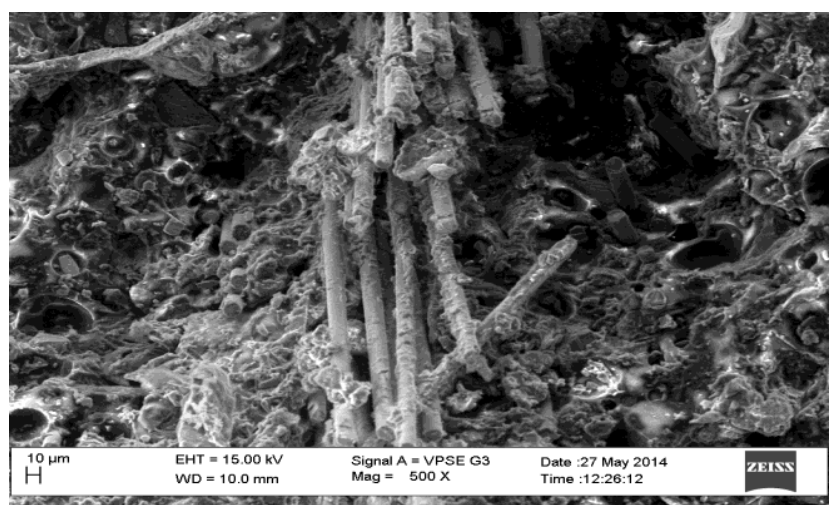

Fig 4.1 - SEM micrograph (500 X Magnification) of CGRP composite with subjected to tensile test

From the Table III, it is observed that tensile strength is increasing with increase in percentage of $\mathrm{Al}_{2} \mathrm{O}_{3}$, it is $64.36 \%$ increased which is very significant.

The variation is also linear; the increasing tensile strength up to $15 \% \mathrm{Al}_{2} \mathrm{O}_{3}$, for every $5 \%$ addition of $\mathrm{Al}_{2} \mathrm{O}_{3}$ increasing in tensile strength is $10.91 \%$. Whereas, increase in tensile strength for $5 \%$ more addition of $\mathrm{Al}_{2} \mathrm{O}_{3}$, increases the tensile strength is $20.49 \%$. One can observe that, the order of magnitude of increase in tensile strength for $5 \%$ more addition is almost twice.

$\mathrm{SiC}$ has $410 \mathrm{GPa}$ elastic modulus, whereas $\mathrm{Al}_{2} \mathrm{O}_{3}$ has $300 \mathrm{GPa}$,it is evident that increase in tensile strength for the decrease in $\mathrm{SiC}$ is around $10 \%$ and increase in $5 \%$ of $\mathrm{Al}_{2} \mathrm{O}_{3}$ when $\mathrm{SiC}$ has become 0 is $20 \%$. Hence,elastic modulus of $\mathrm{SiC}$ and $\mathrm{Al}_{2} \mathrm{O}_{3}$ are contributing to the increase in overall tensile strength.

These observations are also evident from SEM micrographs(Fig-4.1). As could be seen from the plate,GF have got pulled out from the matrix, whereas more GFs have broken in a brittle manner. These surfaces bonding energy between GF and resin is lesser when compared with that of $\mathrm{Al}_{2} \mathrm{O}_{3}, \mathrm{SiC}$ and other fillers. This means that the contribution of GF for the increase in tensile strength is not significant. It is the larger interfacial attractive forces between the fillers and their properties which have contributed to the increase in tensile strength. It can also be observed from SEM micrographs that very few of these particles are still in their location and these have not fractured.

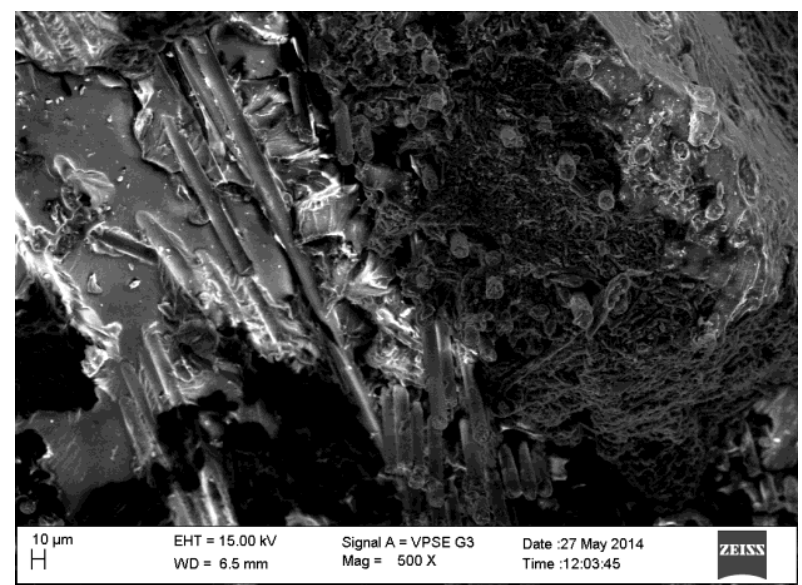

Fig 4.2 - SEM micrograph (500 X Magnification) of CGRP composite with subjected to Impact test

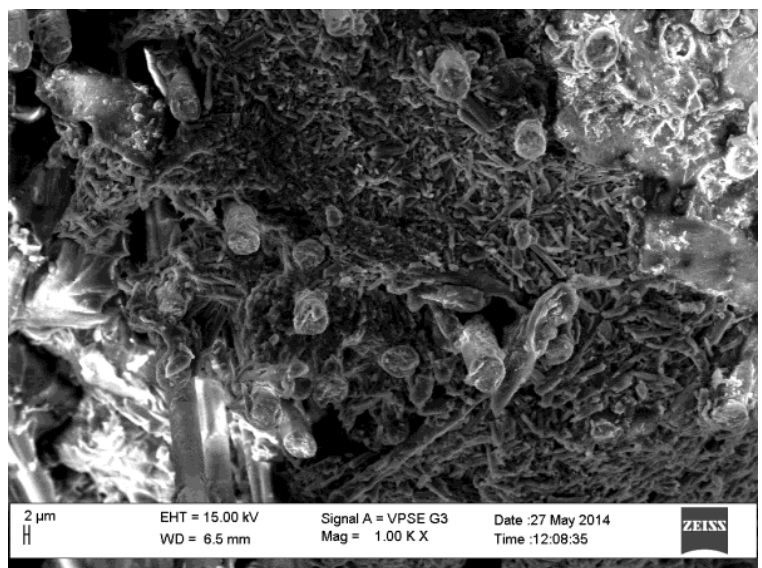

Fig 4.3 - SEM micrograph (1.0K X Magnification) of CGRP composite with subjected to Impact test 
Figure 4.2 and 4.3 is showing SEM micrograph of the specimen having $5 \% \mathrm{SiC}$ and $15 \% \mathrm{Al}_{2} \mathrm{O}_{3}$, giving the highest value of impact strength. The main fractured constituent due to impact load are glass fibers which have got the lowest fracture toughness $\left(1 \mathrm{MPa} \mathrm{m} \mathrm{m}^{1 / 2}\right)$, these are indicated by the fractured glass fibers appearing as bright cylindrical columns. Most of the other particles have got embedded in the matrix including some broken GFs, this is appearing as the darker fibrous spot.

Obviously, the increase in impact strength is basically due to the presence of higher percentage of $\mathrm{Al}_{2} \mathrm{O}_{3}$ and lower percentage of $\mathrm{SiC}$.

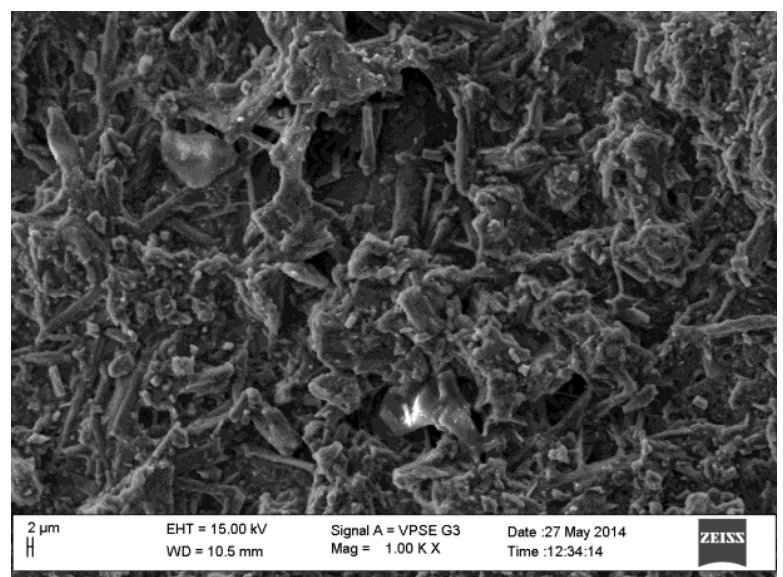

Fig 4.4- SEM micrograph (1.0K X Magnification) of CGRP composite with subjected to wear test

Figure 4.4is showing SEM micrographs for the specimen having $10 \% \mathrm{SiC}, 10 \% \mathrm{Al}_{2} \mathrm{O}_{3}$ at the maximum load. The wear Debris of GFsappears as shorter brighter particles. Bright smaller dot represent $\mathrm{Al}_{2} \mathrm{O}_{3}$ and somewhat larger bright spots are representing $\mathrm{SiC}$ particles. The Graphite, carbon and sodium sulphide which have been used as lubricants do not appear predominantly for identification.

One can observe from the micrographs that the wear debris of glass fiber and the filler particles have got embedded on the plateaus formed on the surface of composite, the particles which are not worn are present in the dark portions of the SEM micrographs.

Higher thermal conductivity of $\mathrm{SiC}$ has softened the matrix which softened the matrix which facilitated the formation of plateaus, which have created a protective shield against wear.

\section{CONCLUSIONS}

The present study and analysis of results had led to the following conclusions

1. $10 \% \quad \mathrm{Al}_{2} \mathrm{O}_{3}$ and $10 \% \mathrm{SiC}$ has shown minimum Specific Wear rate $\left(4.39 * 10^{-4} \mathrm{~mm}^{3} / \mathrm{Nm}\right)$ and could be considered as optimum percentage of these fillers for further development.

2. The impact energy for the composite having $05 \%$ $\mathrm{SiC}$ and $15 \% \mathrm{Al}_{2} \mathrm{O}_{3}$ has shown the maximum impact strength, which is due to the fracture toughness of both $\mathrm{SiC}$ and $\mathrm{Al}_{2} \mathrm{O}_{3}$ are maximum in comparison with other fillers.

3. The tensile strength increased is $64.36 \%$, which is very significant this is due to high tensile modulus of both $\mathrm{SiC}$ and $\mathrm{Al}_{2} \mathrm{O}_{3}$.

4. The general conclusion is that the addition of $\mathrm{SiC}$ and $\mathrm{Al}_{2} \mathrm{O}_{3}$ has significantly contributed to the improvement in wear resistance, impact and tensile strengths predominantly by $\mathrm{Al}_{2} \mathrm{O}_{3}$.

\section{ACKNOWLEDGEMENTS}

The authors thank, Sri Jayachamarajendra College of Engineering, Mysore 570006, India and ATME College of Engineering, Mysore 570028 for providing all the support for carrying out this research.

\section{REFERENCES}

[1] P.D. Mangalgiri, Polymer-matrix Composites for High-temperature Applications, Aeronautical Development Agency. Defense Science Journal, Vol. 55, No. 2,pg 175-93, 2005.

[2] Seran Choi, HyunguIm, Jooheon Kim, Flexible and high thermal conductivity thin films based on polymer: Aminated multi-walled carbon nanotubes/micro-aluminum nitride hybrid composites. Composites: PART A 43: 1860-1868, 2012.

[3] Mathieu Robert and BrahimBenmokrane, Behavior of GFRP Reinforcing Bars Subjected to Extreme Temperatures.Journal of Composites for Construction: 353-360 2010.

[4] GauravAgarwal, Amar Patnaik and Rajesh Kumar Sharma, Thermo-mechanical properties of silicon carbide-filled chopped glass fiber-reinforced epoxy composites. International Journal of Advanced Structural Engineering, 5: 21: 1-8. 2013.

[5] Jose Miguel da Costa Pires, Mechanical behaviour at elevated temperatures of GFRP pultruded composite profiles.

[6] Mohammed H. Al-Saleh, UttandaramanSundararaj, Review of the mechanical properties of carbon nanofiber/polymer composites. Composites: Part A: 42: 2126-2142. 2011.

[7] Jin-Woo Kim, Hyoung-Seok Kim, Dong-Gi Lee, Tensile Strength Of Glass Fiber-Reinforced Plastic By Fiber Orientation And Fiber Content Variations, International Journal of Modern Physics: Conference Series Vol. 6 640-645, 2012.

[8] Jane Maria Faulstich de Paiva, SérgioMayerc, Mirabel CerqueiraRezende,Comparison of Tensile Strength of Different CarbonFabric Reinforced Epoxy Composites, Materials Research, Vol. 9, No. 1, 83-89, 2006

[9] D. Chandramohan, Dr. K. Marimuthu, Tensile and Hardness Tests Natural Fiber Reinforced Polymer Composite Materials, IJAEST, Vol. 6, Issue 1,: 97104, 2011. 
[10] Robert Valek, Jaroslav Hell, Impact Properties Of Polymeric Nanocomposites With Different Shape Of Nanoparticles, 1-15, 2011.

[11] P.V. Vasconcelos, F.J. Lino, A. Magalhaes, R.J.L. Neto, Impact fracture study of epoxy-based composites with aluminium particles and milled fibres, Journal of Materials Processing Technology 170, 277-283, 2005.

[12] D. Chandramohan J. Bharanichandar, Impact test on natural fiber reinforced polymer composite materials, Applied Science Innovations, 5/3,: 314 320, 2013.

[13] S.Bahadur and Y Zheng, Mechanical and tribological behavior of polyester reinforced with short glass fibers, Mechanical Engineering Department, Iowa State University, Ames, Iowa, USA. Wear,: 137: 251- 266, 1990.

[14] Aida Besnea, Dan Trufasu, Gabriel Andrei, Lorena Deleanu, Wear Behaviour of PolyphenyleneSulphideComposites During Dry Sliding Tests, Mechanical Testing and Diagnosis, Vol. 2, Issue 2, 15-20, 2012.

[15] ChittaranjanDeo, S. K. Acharya, Effects of fiber content on abrasive wear of Lantana Camara fiber reinforced polymer matrix composites, Indian Journal of Engineering and Mechanical Sciences, Vol. 17: 219-223, June 2010. 